\title{
KEMUNDURAN DAN KEHANCURAN KERAJAAN MUGHAL
}

\author{
M. Djamaluddin Miri \\ Institut Agama Islam Negeri (IAIN) Sunan Ampel Surabaya. Jalan Ahmad Yani. Telp. 081236842241. e_mail: \\ Djamal_miri@yahoo.com
}

Abstract

Mughal was one of the Islamic Kingdoms that stay long for about 342 years, starting from Sultan Zahr al-Din Muhammad (1483-1530 A.D) until Sultan Siraj al-Din Bahadur Syah (1837-1858 A.D). There are two prominent factors which caused the Kingdom of Mughal separated each other and faced the decrease, internal and external factors. Internally, the Kingdom of Mughal faced the decrease because of no system and mechanism on power succession, and also the lack leadership integrity of the next generation who descended the former leaders. The hedonism life style also became the main cause of the complicated political situation on the Kingdom. Moreover, the political policy which tends to be more puritanical and ideological also ruined the governmental system. Those internal factors, then, caused weak political control and powerless authority of the Kingdom in front of other kingdoms. As a consequence, many rebellions happened everywhere. It absolutely made the power of the Kingdom one by one belongs to other kingdoms.

Key words: kingdom of mughal, dominance, politic 


\section{Pendahuluan}

Sesungguhnya romantisme kejayaan peradaban Islam mencapai puncaknya pada zaman klasik, tepatnya pada masa Dinasti Bani Abbasiyah (750-850 M). Namun sebelumnya Dinasti Bani Ummayyah juga tak bisa dilupakan begitu saja. Sebab sesungguhnya kemajuan Bani Abbsiyah adalah melanjutkan apa yang telah diperjuangkan oleh kekhalifahan Bani Umayyah.

Namun kejayaan yang telah dirintis tersebut tidak bisa bertahan lama. Ada beberapa faktor yang menyebabkan jatuhnya dua dinasti besar dalam sejarah peradaban Islam tersebut. Diantaranya adalah ketidakpuasan sejumlah besar orang-orang non-Arab yang memeluk Islam. Faktor kedua adalah meningkatnya perpecahan di antara kabilah-kabilah Arab. Ketiga yaitu kekecewaan sejumlah besar orang yang prihatin akan keadaan agama (Montgomery Watt, 1990: 29). Keempat terjadi ketidakpuasan dalam pembagian jabatan di kalangan internal yang menyebabkan terjadinya perang saudara, dan faktor terakhir adalah kurangnya pengawasan terhadap luasnya wilayah yang harus dikendalikan.

Setelah jatuhnya dinasti Abbasiyah, dalam waktu kurun waktu yang begitu lama muncullah kerajaan Islam terbesar yang berdiri di India, yaitu kerajaan Mughal yang berdiri tegak selama tiga abad (1526-1858 M). Kerajaan ini didirikan oleh Babur, seorang keturunan Mongol pada tahun $1526 \mathrm{M}$. Dalam kurun waktu kurang lebih 150 tahun, kerajaan yang menganut agama Islam tersebut telah memberikan warna tersendiri di tengah-tengah masyarakat yang mayoritas beragama Hindu di India.

Tentu saat ini, gaung kebesaran Islam warisan Dinasti Mughal sudah tidak terdengar lagi. Namun perlu diketahui bahwa lahirnya negara Islam Pakistan tidak terlepas dari perkembangan Islam pada masa dinasti tersebut. Bahkan sisa-sisa kemegahan Dinasti Mughal masih bisa terlihat dari bangunanbangunan-bangunan bersejarah yang masih bertahan hingga sekarang seperti Taj Mahal dan Red Fort (Benteng Merah) yang merupakan artefak peniggalan Shah Jehan.

Kerajaan yang telah mengalami suksesi kepemimpinan sebanyak enam belas kali tersebut adalah suatu prestasi tersendiri dalam khazanah peradaban 
Islam. Terutama implikasi positif, seperti kemajuan di bidang perekonomian, pertanian militer bagi bangsa India saat itu. Namun mengapa kejayaan yang begitu menggema sampai ke Eropa itu akhirnya mengalami keruntuhan? Sehingga penulis perlu mencari faktor-faktor apakah yang menyebabkan jatuhnya kerajaan Mughal tersebut?

\section{Kemunduran dan Kehancuran Kerajaan Mughal}

Ada dua faktor kemunduran dan kehancuran kerajaan Mughal, yaitu faktor internal dan eksternal. Kedua faktor ini memiliki hubungan yang sangat erat antara satu dengan yang lain.

\section{Faktor Internal}

a. Tidak Adanya Kejelasan Lajur Suksesi

Ketidakjelasan suksesi menimbulkan berbagai kemelut berkepanjangan di antara para anggota keluarga kerajaan yang merasa mempunyai wewenang dan kemampuan untuk menjadi raja. Akibatnya, perebutan kekuasaan melalui kekerasan dan bahkan perang saudara sering tidak terhindarkan lagi (Mu'nis, 1973: 486). Misalnya Aurangzeb, ia menjadi raja setelah melakukan perang saudara dengan melibatkan banyak pangeran, seperti Murad, Syuja' dan Syikoh (Mahmudunnasir, 1994: 368-369).

Sepeninggal Aurangzeb, kekuasaan diperebutkan oleh ketiga orang anaknya dan akhirnya dimenangkan oleh Bahadur Syah dengan bantuan bangsa Rayput yang dahulunya justru menjadi musuh besar bagi kerajaan Mughal (Israr, 1978: 108). Demikian halnya sepeninggal Bahadar Syah, penggantinya Azimuz Syah yang merupakan anaknya ternyata telah ditentang oleh Zulkifar Khan, anak Azad Khan, Wazir Aurangzeb. Setelah Azimuz Syah meninggal, anaknya yang bernama Jihandar Syah menggantikannya menjadi raja, namun ditentang oleh adiknya Farukh Syah dan berhasil menyingkirkannya pada tahun 1713 M. Kekuasaan Farukh Syah tidak pula bertahan lama, karena pada tahun 1719 ia tewas di tangan para pendukungnya sendiri, dan kedudukannya digantikan oleh Muhammad Syah yang bertahan sampai tahun 1748 
M. sebelum kemudian diusir oleh Nadir Syah dari suku Afsyar yang sebelumnya berhasil mengalahkan dinasti Safawiyah di Persia (Yatim, 1996: 160).

Adanya konflik-konflik intern yang berkepanjangan tersebut mengakibatkan dan melemahkan pengawasan terhadap pemerintahan daerah sehingga akhirnya terjadi disintegrasi, selain merusak persatuan dan kesatuan.

Beberapa daerah mulai melepaskan loyalitasnya kepada pemerintah pusat, bahkan cenderung memperkuat posisi pemerintahan masingmasing seperti, Hiderabat dan Nizam al Mulk, Marathas oleh Shivaji, Rajput oleh Si Jai Singh, Punjab oleh kelompok Sikh, Oudh oleh Sadat Khan, Bengal oleh Syuja' al Din, selain wilayah-wilayah pantai yang mulai dikuasai oleh para pedagang asing, terutama EJC dari Inggris (Yatim, 1996: 161).

b. Lemahnya Para Pewaris Tahta Kerajaan

Kebanyakan pewaris tahta kerajaan, terutama setelah Aurangzeb adalah orang-orang yang lemah dalam kepemimpinan. Hal ini terbukti, bahwa dari 29 Sultan yang pernah memimpin kerajaan Mughal hanya beberapa saja yang tercatat mampu bertahan lebih dari 20 tahun (Boswirh, 1993: 235). Sedangkan selebihnya hanya mampu berkuasa dalam waktu yang relatif singkat, bahkan ada yang hanya beberapa bulan saja.

Adapun yang pernah berkuasa adalah (Arnold, 1995: 227):

1. Zahiruddin Babur (932-937 H/1526-1530 M).

2. Nasiruddin Humayan (937-947 H/1530-1540 M).

3. Sultan-sultan Suri dari Delhi (947-962 H/1540-1555 M).

4. Humayun $(962-963 \mathrm{H} / 1555-1556 \mathrm{M}) /$ memeritah dua kali.

5. Jalal al Din Akbar I (963-1014 H/1556-1605 M).

6. Nur al Din Jahangir (1014-1037 H/1605-1627 M).

7. Dawar Bakhsy $(1037 \mathrm{H} / 1627-1628 \mathrm{M})$.

8. Syihab al Din Syah Jihan (1037-1068 H/1628-1657 M).

9. Murad Bakhsy (1068 H/1657 M). 
10. Syah Syuja' (1068 H/1657 M).

11. Muhy al Din Aurangzeb Alamgir I (1068-1118 H/1658-1707 M).

12. A'zam Syah (1118-1119 H/1707 M).

13. Kam Bakhsy (1119 H/1707 M).

14. Syah Alam Bahadur Syah (1119-1124 H/1707-1712 M).

15. Azhim as Sha'n (1124 H/1712 M).

16. Mu'iz al Dil Jihandar (1124 H/1712 M).

17. Farrukh Syiar (1124-1131 H/1713-1719 M).

18. Syams al Din Rafi' al Darajat (1131 H/1719 M).

19. Rafi' al Daulah Syah Jihan II (1131 H/1719 M).

20. Niku Siyar (1131 H/1719 M).

21. Nashir al Din Muhammad Syah (1131-1161 H/1719-1748 M).

22. Ahmad Syah Bahadur (1161-1167 H/1748-1754 M).

23. 'Aziz al Din Alamgir II (1167-1173 H/1754-1760 M).

24. Syah Jihan III (1173 H/1760 M).

25. Jalal al Dil 'Ali Jawhar Syah Alam II (1173-1201 H/1760-1788 M).

26. Bidar Bakht (1202-1203 H/1788 M).

27. Syah Alam II (1203-1221 h/1788-1806 M).

28. Sultan Akbar II (1221-1253 H/1806-1837 M).

29. Siraj al Din Bahadur Syah II (1837-1858 M).

Orang-orang yang berakuasa hanya beberapa orang saja yang mampu bertahan lama. Selain itu, walaupun mereka mampu bertahan lama, namun tidak semuanya berada dalam masa kejayaan. Beberapa di antaranya berada dalam masa sulit, seperti Nashir al Din Muhammad Syah yang sejak tahun 1739 M. menjadi kerajaan boneka dari Nashir Syah yang melakukan penaklukan ke kerajaan Mughal (Yatim, 1996: 160), dan Jalal al-dina Alam berada dalam kekuasaan Ahmad Khan Durrani dari Afghan, meskipun tetap diizinkan memakai gelar Sultan (Yatim, 1996: 161).

Demikian halnya pada Sultan Akbar II, pemerintahannya telah memberikan konsesi kepada IEC untuk mengembangkan usahanya di India dengan konpensasi jaminan kehidupan bagi raja dan keluarga istana. Hal ini berarti, kekuasaan sebenarnya sudah berada di tangan Inggris, meskipun 
kedudukan dan gelar Sultan masih boleh dipertahankan (Yatim, 1996: 162). a. Pola Kehidupan Mewah dan Boros

Pola kehidupan mewah dan boros banyak dilakukan oleh elite penguasa, sehingga banyak membebani anggaran belanja negara yang kemudian mengakibatkan kenaikan pajak, baik terhadap para petani di pedesaan maupun masyarakat kota (Mu'nis, 1973: 85).

Berbagai kemewahan tersebut antara lain sebagaimana yang dilakukan oleh Sultan Akbar dengan banyak membangun masjid-masjid dan istana-istana yang sangat indah, seperti Fadifur (Fathpur) Sikri pada tahun 1560 M. Demikian halnya dengan Syah Jehan, sebagian besar harta kekayaan negara untuk membangun masjid dan istana yang super indah, dan bahkan untuk singgasananya saja telah dibuat menyerupakan burung merak berlapiskan emas dan berbagai permata yang sangat mahal (Israr, 1978: 107).

Pada masanya pula, telah dibangun Taj Mahal di kota Agra tahun 1613 M. sebagai lambang cintanya kepada mendiang permaisurinya, Mumtaz Mahal. Taj Mahal yang terbuat dari albast (marmer putih) dengan luas 100 x $110 \mathrm{~m}$, memiliki 4 pintu masuk yang besar dengan ketinggian $20 \mathrm{~m}$, dan dibangun menurut langgam Persia dilengkapi dengan kubah penutup setinggi $80 \mathrm{~m}$, dibuat untuk menciptakan bangunan yang belum pernah didirikan manusia sebelumnya. Untuk itu, maka Syah Jehn telah mengundang para arsitek dari Italia, Persia dan negeri-negeri lainnya serta dibantu oleh 20.000 pekerja selama 17 tahun. Di tengah ruangannya yang sangat indah, kemudian dimakamkan permaisurinya berdampingan dengan dirinya setelah kematiannya dengan makam yang sangat indah bertaburkan berbagai permata lazuardi, zabarajad dan lainnya (Israr, 1978: 114115), sehingga kelak menjadi maha karya seni dan sebagai salah satu keajaiban dunia. Pada akhirnya, berbagai kemewahan dan pemborosan tersebut menimbulkan ketidak senangan di kalangan rakyat yang merasa ikut dibebani dengan kenaikan pajak dan pungutan lainnya, selain melemahkan perekonomian negara. 
b. Kebijakan Puritanisme

Kebijakan puritanisme oleh sultan Aurangzeb dan pengislaman orang-orang Hindu secara paksa demi menjadikan tanah India sebagai negara Islam, dengan menyerang berbagai praktek sosial keagamaan yang dikembangkan oleh masyarakat Hindu (Hodgson, 1974: 96), di samping memperlakukan diskriminasi yang mencolok terhadap masyarakat Hindu dan memberi hak-hak istimewa kepada masyarakat Islam (Boswirh, 1993: 237), telah menyebabkan kalangan Hindu memusuhi dan bersekongkol dengan musuh-musuh Mughal, sehingga akhirnya meletuslah berbagai pemberontakan-pemberontakan seperti yang dilakukan oleh kalangan Marathas di bawah pimpinan Santaji Ghjorpade dan Dhanaji Jadev (Mahmudunnasir, 1994: 373).

c. Pemaksaan Ajaran Syi'ah

Pemaksaan ajaran Syi'ah diberlakukan oleh Muazzam, putera tertua Sultan Aurangzeb yang sebelumnya menjadi penguasa di Kabul bergelar Bahadur Syah (1707-1712 M).

Pemaksaan ini bertentangan dengan kebijaksanaan para Sultan Mughal sebelumnya, seperti Syah Jehan yang justru berkeinginan mempersatukan Asia Tengah dan India dalam sebuah kekaisaran Sunni (Boswirh, 1993: 273).

Akibat dari pemaksaan tersebut, maka Mughal dihadapkan pada perlawanan penduduk Lahore di saat harus berharapan pula dengan perlawanan yang dilakukan oleh kaum Syikh sebagai akibat dari tindakan Sultan sebelumnya (Yatim, 1996: 159-160).

\section{Faktor Eksternal}

a. Adanya pemberontakan-pemberontakan yang dilakukan oleh orang-orang Hindu dan Sikh, selain akibat dari kebijakan politik dan ekonomi para penguasa Mughal, seperti puritanisme dan pungutan pajak yang sangat tinggi untuk membiayai kegemaran hidup mewah dan boros para penguasa, kemungkinan juga oleh sebab-sebab lain, seperti perasaan dendam kesumat sebelumnya berkaitan dengan penaklukan kota Khithor oleh Sultan Akbar (1556-1605 M) yang memusnahkan seluruh penduduknya berjumlah 30.000 
jiwa. Kota ini dapat direbut setelah seluruh penduduknya mengorbankan diri termasuk wanita dan anak-anak, dengan memilih membunuh diri melompot ke dalam nyala api yang amat besar daripada menjadi tawanan Sultan Akbar (Israr, 1978: 105).

b. Adanya serangan-serangan dari luar, seperti yang dilakukan oleh Nadir Syah pada tahun 1739 M. karena menganggap kerajaan Mughal telah banyak sekali memberikan bantuan kepada para pemberontak Afghan di daerah Persia.

c. Demikian halnya dengan serangan yang dilakukan oleh Ahmad Khan Durrani dari Afghan tahun 1761 M. sehingga membuat Mughal akhirnya menjadi kerajaan boneka, meskipun Syah Alam selaku raja ketika itu masih diperkenankan untuk memakai gelar Sultan (Boswirh, 1993: 238) d. Datangnya kekuatan Inggris dengan perusahaan dagangnya IEC

Ada dua periode penyerangan yang dilakukan oleh Inggris:

Pertama, ketika kerajaan Mughal dalam keadaan lemah saat berada di bawah kekuasaan Ahmad Khan Durrani dari Afghan tahun 1671 M. Setelah melakukan peperangan yang berlangsung berlarut-larut, akhirnya Syah Alam membuat perjanjian damai dengan menyerahkan Qudh, Bengal dan Orisa kepada Inggris.

Kedua, pada masa Bahadur syah pada tahun 1857 M. periode ini, Bahdur Syah (1837-1858 M) sebenarnya tampil sebagai lambang perlawanan bagi pemberontakan rakyat melawan Inggris akibat pungutan pajak yang sangat tingi yang diberlakukan oleh IEC. Namun pemberontakan tersebut dengan mudah dapat dipadamkan oleh Inggris karena mendapat dukungan dari beberapa penguasa lokal Hindu dan Muslim (Boswirh, 1993: 238).

Bahadur Syah kemudian dapat ditangkap dan diasingkan ke Burma sampai wafat. Jenazahnya dimakamkan di dekat sebuah masjid di kota Rangoon (Israr, 1978: 108). Sejak penangkapannya tersebut, maka berakhirlah sejarah kekuasaan Mughal setelah berjaya lebih dari tiga abad di India dengan banyak meninggalkan kenangan indah tiada tara, terutama di bidang seni. 


\section{Simpulan}

Jatuhnya Kerajaan Mughal secara mendasar disebabkan oleh dua faktor internal dan eksternal. Faktor internal tersebut adalah kurang terencananya proses suksesi yang menyebabkan perebutan kekuasaan dan perang saudara. Begitu juga faktor lemahnya pengawasan di pemerintahan tingkat daerah yang berkibat terjadinya disintegrasi. Sedangkan dari faktor eksternal adalah munculnya pemberontakan-pemberontakan oleh orang-orang Hindu dan Sikh, dan serangan Raja Ahmad Khan dari Afganistan. Begitu pula kebijakan menaikkan pajak yang sangat tinggi serta terjangkitnya kehidupan biros dan bermewah-mewahan di kalangan kerajaan. Puncaknya saat masuknya Kerajaan Britania pada tahun 1600 m dan menaklukkan Kerajaan Mughal pada tahun $1757 \mathrm{M}$.

\section{Daftar Pustaka}

Arnold, Thomas W. 1995. Sejarah Da'wah Islam. Terjemahan oleh H.A. Nawawi Rambe. Jakarta: Wijaya Jakarta.

Boswirh, C.E. 1993. Dinasti-Dinasti Islam. Terjemahan oleh Ilyas Hasan. Bandung: Mizan.

Facruddin, Fuad Muhamamd. 1985. Perkembangan Kebudayaan Islam. Jakarta: Bulan Bintang.

Hodgson, Murshal G.S. tt. 1974. The Venture of Islam. Vol.III. Chicago: The University of Chicago Press.

Israr, C. 1978. Sejarah Kesenian Islam. Jilid 2. Jakarta: Bulan Bintang.

Mahmudunnasir, Syed. 1994. Islam Konsepsi dan Sejarahnya. Terjemahan oleh Adang Affandi, Bandung: PT. Remaja Rosdakarya.

Mu'nis, Husain. 1973. 'Alam al Islami. Mesir: Dar al Ma'arif.

Pan Americana Copyright. 1972. The Encyclopedia Americana, Vol. 19. New York: American Corporation. 
Yatim, Badri. 1996. Sejarah Peradaban Islam. Jakarta: Raja Grafindo.

Watt, W.Montgomery. 1990. Kejayaan Islam: Kajian Kritis dari Tokoh Orientalis. Yogyakarta: Tiara Wacana.

el-Harakah, Vol. 11, No. 3, Tahun 2009 